\title{
A PSYCHOLOGIAL ANALYSIS OF THE MAIN CHARACTER IN FYODOR DOSTOEVSKY'S THE GAMBLER
}

\author{
Achmad Fanani \\ (Unipdu - Jombang) \\ achmadfanani@fbs.unipdu.ac.id
}

\begin{abstract}
The novel "The Gambler" tells about a young teacher named Alexei Ivanovich who works for a Russian general who was once a wealthy man. This novel is an image of the writer's addiction to roulette gambling. Dostoevsky finished the writing of this novel in a very short time in order to settle his gambling debts. The analysis shows that the main character can be said as a pathological gambler. This is because there are at least five of 10 characteristics of a pathological gambler in his character. They are preoccupation, tolerance, escape, chasing (always trying to win back what is lost), loss of self-control, and bailout (relying on money from others).

Keywords: Gambling, Pathological Gambler
\end{abstract}

ABSTRAK

The Gambler bercerita tentang seorang guru muda, Alexei Ivanovich, yang bekerja untuk seorang Jendral Russia yang kaya raya. Novel ini menceritakan tentang bagaimana seseorang menjadi kecanduan dengan judi. Penulis novel ini, Dostoevsky, menulis novel ini dalam kurun waktu yang cepat untuk maksud pelunasan hutang. Hasil penelitian menunjukkan bahwa Alexei Ivanovich bisa dikatakan sebagai seorang pejudi patologis karena memiliki lima dari sepuluh karakteristik seorang pejudi patologis. Karakteristik tersebut adalah: preoccupation, tolerance, escape, chasing (selalu mengejar apa yang hilang), loss of control, and bailout (mengandalkan uang dari orang lain).

Katakunci: Perjudian, Pejudi patologis

\section{A. INTRODUCTION}

\section{B. THEORETICAL FRAMEWORK}

Gambling, as well as prostitution, has existed on earth since the beginning of human civilization. In Mahabharata story, it is told that the Pandavas lost their kingdom and were thrown into the forest for 13 years for losing the gambling game against Kurava. In the western world gambling behavior has been known since the ancient Greece. The diversity of gambling games and their very easy techniques make it quickly spread all over the world.

Just like in other parts of the world, gambling behavior also widely spreads in Indonesian society. However, because the law in Indonesia does not allow the existence of gambling, the activities are done in secret. Gambling among
Indonesian people can be found in various layers of society. Gambling forms are diverse, from traditional ones such as gambling dice, cock fighting, guessing songs to the use of advanced technology such as gambling via mobile phones or the internet.

The Gambler is a novel that was created by Fyodor Dostoevsky. The novel tells about a young teacher named Alexei Ivanovich who works for a Russian general who was once a wealthy man. This novel, as seen on the back cover of the novel, is a reflection of the writer's addiction to roulette gambling. Dostoevsky finished the novel in quick time so he could settle his debts due to his gambling habit.

This article discusses how gambling can be so addictive and whether the main character in this novel, Alexei Ivanovich, can be said as a gambler who is pathological or not, a level of gamble 
which is the most severe level. The analysis of Alexei Ivanovich's character as a Gambler

In this novel, the main character, Alexei Ivanovich, experiences anxiety because of his gambling habit. His anxiety can be seen from his feelings of concern, uncertainty, or fear either from unknown or known source (Fanani, 2014). Because this novel tells a lot about a person who is addicted to gambling, it is interesting to see if Alexei Ivanovich can be categorized as a pathological gambler or not. Pathological gambler is also called compulsive gambler. The characteristic of this type of gambler is one's inability to escape from the impulses to gamble. $\mathrm{He}$ is obsessed with gambling and constantly increases the frequency of gambling and the number of bets, without being able to consider the negative consequences of such behavior, whether on his own, family, career, social or environmental relationships.

The American Psychiatric Association or APA defines the characteristics of pathological gambling as follows: "The essential features of pathological gambling are as follows: a progression, in gambling frequency and amounts wagered, in the preoccupation with gambling and in obtaining monies with which to gamble and a continuation of gambling involvement despite adverse consequences ". (Carson \& Butcher, 1992)

Although this pattern of gambling behavior does not involve dependence on a particular chemical, experts say that gambling behavior that has been included in this level can be classified as an addictive disorder. DSM-IV (Diagnostic and Statistical Manual of Mental Disorders-fourth edition) delivered by APA categorizes pathological gambling as a mental disorder which is also known as Impulse Control Disorder. It is estimated that DSM-IV is experienced by $1 \%-3 \%$ of the adult population. Individuals who are diagnosed with this type of behavioral disorder are often identified as highly competitive people, in urgent need of consent or opinion of others and susceptible to other forms of addiction behavior. Individuals who are included in the pathological gambling category are often accompanied by health and emotional problems. Such problems include drug addiction (Napza), alcoholics, gastrointestinal and respiratory diseases, depression, or problems related to sexual function (Pasternak \& Fleming, 1999).

The individual criterion that can be classified as a pathological gambler according to DSM-IV Screen (the tool used to measure the level of gambler) is if the individual shows 5 (five) factors or more of the following factors:

- Preoccupation. Obsessed with gambling (for example, obsessed with repeating past gambling experiences, it's hard to distract anything other than gambling, or specially thinking about ways to earn money through gambling)

- Tolerance. The need to gamble with a tendency to increase the amount of money (bets) in order to achieve a desired pleasure / satisfaction

- Withdrawal. Becoming easily agitated and irritable every time trying to stop gambling

- Escape. Making gambling a way to escape life's problems or unpleasant feelings (eg, guilt, powerlessness, anxiety, depression, sadness)

- Chasing. After losing the gamble, tend to again gamble again to pursue victory in order to get a breakeven point

- $\quad$ Lying. Lying to family members, counselors or therapists or others about his involvement in gambling

- Loss of control. Always failed to control, reduce or stop gambling behavior

- Illegal Acts. Engaging in unlawful acts, such as fraud, theft, forgery, etc., in order to support the financial costs of gambling.

- $\quad$ Risked significant relationship. Endangering or causing damage to friendships with people who play a significant role in life, job losses, dropouts or families become cluttered, or career opportunities are lost.

- Bailout. Relying on others to give money to themselves or their families in order to reduce the financial burden of gambling 
In the novel there are some of the above characteristics existed in Alexey Ivanovich's personality. The main character experiences at least five characteristics so that he can be categorized as a pathological gambler. Firstly, we know that Alexey is obsessed with gambling. He never seems to get out of this activity. Since he first started gambling, on Polina's orders, he seemed to be living on gambling, especially roulette. For him, roulette could instantly change his fate; it can make him rich - and also poor instantly (p. 46). And for him, a real man is a man who dares to take risks (page 287). Also for Alexei roulette is just like food. He is not just for fun or entertainment but more as a need that must be met. He lives to gamble and gambling is his life. For him the defeat at the gambling table is not the end of everything. There are still plenty of opportunities to regain what's missing. Every time he loses, even though he is sometimes afraid, he will always try to win it back. For example, on page 225 , he tells how he always tries to get back what he lost because he has a strong conviction to win even up to the last coin.

"Then, I remember, I placed a two-thousandflorin bet on twelve middle numbers, and lost; I risked my gold money, eighty friedrich d'or, and lost. I looked with fear: I grabbed the two hundred florins I still had and risked them on the first twelve numbers - haphazardly, randomly, without thinking! At that moment, a moment of tension, like, perhaps, the feelings experienced by Madame Blanchard as she jumped from a balloon in Paris to earth. "

Of course he did it not only once. Every time he got lost, he always tried to win it back, and so forth. Failure that he experienced did not make him doubtful on him. This is because he had a very strong conviction to win (pp. 56 and 286). Even for the last coin he still had the confidence to win it.

In gambling Alexei had a tendency to always raise the amount of bets, especially when he started winning. At the beginning of the game when he still had a little money he was careful in terms of the amount of stakes. He played in small stakes. But when he began to win and earned a lot of money, he was tempted to earn bigger wins and bet on a larger amount even with the risk of losing his money quickly (page 46).

For Alexei gambling (roulette) was a form of escape. For him gambling was his job. He had no other job he could rely on to earn money, which could save him alive. For him, roulette was the best and fastest place to earn money. In other words he used roulette as a vehicle to build his hopes. "So you still continue your conviction that the roulette is just your escape and salvation?" (Page 29).

Alexei was also very difficult to get away from gambling. He could not get away from gambling when there's money in his hands, no matter how much it was. The gambling in him was like a virus that had spread throughout his brain cells and influenced his way of thinking. He lost control of himself, in this case judgment that affected the way he acted. This caused Mr. Astley not want to give Alexei a lot of money. He knew very well that much or little of the money he gave to Alexei, he would definitely use it to gamble again (page 285).

In many parts of the novel it is illustrated how Alexei often suffered financial problems from losing gambling. He had difficulty in paying hotel expenses and other necessities. Even he was jailed and could come out only because of the mercy of someone who redeemed himself. The money he used to gamble was mostly a gift from others. He basically never got really rich from gambling, although occasionally he got a big win. Even at the end of the story, he needed money from Mr. Astley to follow Polina to Switzerland, although later he used the money to gamble again.

From the above facts, Alexei Ivanovich, the main character in this novel could be said as a pathological gambler. In his personality there are at least 5 or more characteristics of a pathological 
gambler: preoccupation, tolerance, escape, chasing, loss of control, and bailout.

D. Conclusion

From the above description there are several points that can be concluded. First, gambling is a very addictive game. Even a layperson gets trapped in this game when he begins to feel victorious. Little wins from gambling are much sweeter than any other kind of victory. Victory from gambling can make a person feel as a lucky person which consequently makes him always optimistic.

However, victory is actually just the beginning of the main character's defeat. After he gets a victory, he will soon experience many defeats that make him poor and desperate. In other words gambling is the best way to fall into poverty.

The main character in the The Gambler, Alexei Ivanovich, can be said as a gambler who is pathological. This is because he meets at least five of 10 characteristics of a pathological gambler: preoccupation, tolerance, escape (escape), chasing (always trying to win back what is lost), loss of control (loss of self-control), and bailout (and rely on money from others).

\section{References:}

Carson, R. C., \& Butcher, J. N. (1992). Abnormal Psychology and Modern Life. 9th edition. New York: Harper Collins Publishers Inc.

Fanani, A. (2014). Kecemasan Dalam Cerpen An Anxious Man Karya James Lasdun. Diglossia, 53. Papu, J. (2010). www.e-psikologi.com. Retrieved March 10, 2018, from www.e-psikologi.com: //www.e-psikologi.com/epsi/sosial_detail.asp/

I.Pasternak, A. V., \& Fleming, M. (1999). www.basisonline.org. Retrieved March 15, 2018, from www.basisonline.org: http://www.basisonline.org/1999/11/index.htm I 